\title{
DEGRADATION OF 2,4-D AND FLUOMETURON IN COVER CROP RESIDUES
}

\author{
Robert M. Zablotowicz", Martin A. Locke, and Reid J. Smeda*^ \\ Southern Weed Science Research Unit, United States Department of Agriculture, \\ Agricultural Research Service, P. O. Box 350, Stoneville, MS 38776, USA \\ ** Current address: University of Missouri, Department Agronomy, Columbia, MO \\ (Received in USA 8 September 1997; accepted 22 December 1997)
}

\begin{abstract}
Degradation of 2,4-dichlorophenoxyacetic acid (2,4-D) was studied in hairy vetch (Vicia villosa Roth) and rye (Secale cereale L.) residues. Transformation of fluometuron (1,1-dimethyl-3-( $\alpha, \alpha, \alpha$-trifluoro-m-tolyl)urea) was also evaluated in annual ryegrass (Lolium multiforum Lam.) residues. Microflora associated with herbicidedesiccated hairy vetch and rye residues were 100 -fold or greater than soils. Microbial activity (fluorescein diacetate hydrolysis and respiration) were 6-fold or greater in hairy vetch and rye residues than soil. In 14-d studies, 78 to $82 \%$ versus 28 to $40 \%$ of ${ }^{14} \mathrm{C}$-carboxyl-labelled 2,4-D and 48 to $60 \%$ versus 5 to $17 \%$ of ${ }^{14} \mathrm{C}$-ringlabelled 2,4-D were mineralized in soil and crop residues, respectively. Fluometuron can be degraded by $N$ demethylation in ryegrass residues at rates similar to soil, however, high moisture content was required. Degradation of herbicides in cover crop residues was most likely due to limited bioavailability rather than biological activity. (O1998 Elsevier Science Ltd. All rights reserved
\end{abstract}

KEYWORDS - 2,4-D, Fluometuron, Plant Residues, Biodegradation

\section{INTRODUCTION}

Conservation management strategies such as reduced-till are being implemented by growers to minimize soil erosion and conserve soil moisture. Direct seeding of soybeans (Glycine max (L.) Merr.) into herbicidedesiccated rye residues remaining on the soil surface can reduce erosion and aid in conserving water (1). Cover crop residues remaining on the soil surface can also provide varying degrees of weed control $(1,2,3)$. Use of herbicide-desiccated cover crops in a crop production system may impact soil biological and chemical processes, affecting the subsequent fate of agrochemicals. Crop rotations may alter soil chemical/physical properties (4), soil microbial populations (5) and soil enzyme activities (6). Herbicide-desiccated cover crops can have stimulating effects on various soil microbial populations and soil enzyme activities (7). 
The effects of residue management techniques such as no-till on the fate of herbicides has been studied for many herbicides, i.e., alachlor (8), atrazine (9) bentazon (10), chlorimuron-ethyl (11), metolachlor (9), and metribuzin (12). Depending on the herbicide, soil characteristics and herbicide history, differential patterns of herbicide degradation in soil were observed in no-till compared to conventional till soils. Little is known on the transformations of herbicides in crop residues. Interception of herbicides by crop residues, may impede their movement into the underlying soil $(13,14)$. Chlorimuron-ethyl $(15)$ and fluometuron $(16)$ have a greater sorption to cover crop residues compared to soil. Studies on fluometuron degradation (16), indicated it is rapidly degraded in soils previously planted in ryegrass as well as in ryegrass residues compared to soils that were fallow the previous fall.

We studied microbial populations and fluorescein diacetate hydrolysis (FDA) associated with soils and the cover crop residues to ascertain microbial characteristics relative to herbicide degradation. Laboratory studies evaluated the degradation of 2,4-D and fluometuron by cover crop residues relative to soil. 2,4-D can undergo complete metabolism (mineralization) to $\mathrm{CO}_{2}(17-19)$, while fluometuron is metabolized via sequential demethylation and incorporation into bound soil residues with little mineralization $(16,20)$. These assays may reflect the potential for biodegradation of these herbicides in crop residues compared to soil under field conditions.

\section{EXPERMMENTAL}

\section{Soils and Plant Residues}

Soil (Dundee silt loam) and hairy vetch and rye cover crop residues were obtained from soybean plots, while annual ryegrass residues were collected from cotton field plots, near Stoneville, MS. Rye and hairy vetch were sown in the fall. Cover crops and bare ground (winter fallow) treatments in the soybean experiment were sprayed with $1.05 \mathrm{~kg}$ a.i. ha $^{-1}$ paraquat [1,1'-dimethyl-4,4'-bipyridinium ion] in early May. Soil and herbicide-desiccated cover crop residues were collected from bare ground, hairy vetch and rye plots one week later at soybean planting and 6 weeks after planting. Each soil sample was a composite of three 0 to $10 \mathrm{~cm}$ cores $(5 \mathrm{~cm}$ dia.) collected from each of six replicate plots. Plant residues were collected from a 10 by $10 \mathrm{~cm}$ region around each core. Soils and ryegrass residues from the cotton study were collected from a five-year field study investigating tillage and cover crop interactions. Annual ryegrass (hereafter referred to as ryegrass) was seeded in November of the preceding year, and all plots were sprayed with $1.1 \mathrm{~kg} \mathrm{ha}^{-1}$ of glyphosate in early April. In the cotton study, soil $(0-2 \mathrm{~cm})$ was sampled from no-till bare ground (winter fallow) and no-till plots from fall seeded ryegrass plots one month after herbicide application. Soil and ryegrass used in this study was a composite of samples taken from four replicate blocks. Soil and residues were stored at field moisture conditions at $5{ }^{\circ} \mathrm{C}$, and used in the degradation studies within three months of collection. 


\section{Microbiological Techniques}

Moist soils were sieved through a $2.36 \mathrm{~mm}$ sieve prior to processing. Cover crop residues were chopped to less than $2 \mathrm{~cm}$ length. For estimation of microbial populations, cover crop residues were homogenized in a Sorvall Omni Mixer ( Sorvall Instruments, Newton, CT) in phosphate buffer (0.05 M, pH 6.8), at high speed for $2 \mathrm{~min}$. Homogenates were sonicated for $2 \mathrm{~min}$ prior to preparing serial dilutions in phosphate buffer. Total bacteria, Gram-negative bacteria, and fluorescent and total fungi were enumerated by serial dilution plating as described elsewhere $(8,11)$. Colony forming units were calculated on a dry-weight basis of soil or residue transformed to $\log (10)$. Fluorescein diacetate hydrolysis was used to estimate microbial activities of soils and residues (21).

\section{Degradation of 2,4-D in Residues and Soil}

Two studies assessed the potential for mineralization of 2,4-D to $\mathrm{CO}_{2}$ by no-residue soil and by hairy vetch and rye cover crop residues. Soil and residue samples used in this study were a composite from all replicate plots collected during the July sample. Solutions of 2,4-D were prepared from ring ${ }^{14} \mathrm{C}$-labelled or carboxyl ${ }^{14} \mathrm{C}$ labelled compound (>98\% radiochemical purity) (Sigma Chemical Co., St. Louis, MO), each diluted with technical grade 2,4-D (Chem Service, Chester, PA). Biometer flasks (250 ml, Belco, Vineland, NJ,) were used to assess mineralization (22). In the first study, these flasks contained either $40 \mathrm{~g}$ oven-dry equivalents of soil collected from no-residue control plots or 8-g equivalents of oven-dry vetch or rye residues. Samples were

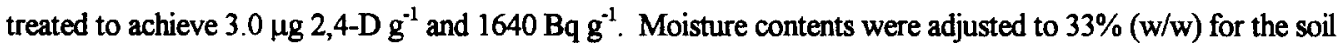
and $66 \%(w / w)$ for the residues and flasks were incubated at $28{ }^{\circ} \mathrm{C}$. In the second study, the amounts of soil and cover crop residues were halved, but 2,4-D concentration and moisture content were identical. Six replicates were used in both experiments. Side-arms of the biometer flasks contained $10.0 \mathrm{~mL}$ of $1.0 \mathrm{~N} \mathrm{NaOH}$ to trap evolved $\mathrm{CO}_{2}$. The $\mathrm{NaOH}$ solutions were removed typically every 2 days and replaced with fresh solution. Aliquots of $\mathrm{NaOH}$ were added to Hi-Ionic-Fluor (Packard, Meriden, $\mathrm{CT}$ ) scintillation cocktail and the absorbed ${ }^{14} \mathrm{CO}_{2}$ was determined using a liquid scintillation counter (LSC) (Packard TriCarb 4000 series, Packard Instrument, Meriden, CT).

After $14 \mathrm{~d}$ incubation, soils and residues treated with ring-labelled 2,4-D were extracted three times with $60 \mathrm{~mL}$ methanol. Radioactivity in the extracts was determined by LSC using Ecolume (ICN, Costa Mesa, CA) scintillation cocktail. In the second study, the initial two methanol extracts were reduced to $10 \mathrm{~mL}$ in a centrifugal evaporator and distilled water was added to $50 \mathrm{~mL}$. The aqueous solution was acidified to $\mathrm{pH} 3.0$ with $1.0 \mathrm{~N} \mathrm{HCl}$ and eluted though a C-18 solid phase extraction column (Baker, Phillipsburg, PA). The residual 2,4-D was removed from the $\mathrm{C}-18$ column with $3.0 \mathrm{~mL}$ of methanol. Methanol extracts were spotted on silica gel TLC plates ( $250 \mu \mathrm{m}$ thick with $3.3 \mathrm{~cm}$ pre-adsorbent layer) and developed for $10 \mathrm{~cm}$ with Benzene:Acetic acid 50:4 (v:v). The distribution of radioactivity in the chromatogram was analyzed with a Bioscan System 200 Imaging Scanner (Bioscan, Washington D.C.). The Rf values of 2,4-D and 2,4-dichlorophenol were 0.16 and 0.40 respectively. Residual radioactivity in extracted soils and residues were determined by oxidation (Packard 
306 Oxidizer) and LSC. In the second study, total $\mathrm{CO}_{2}$ evolved (respiration) was determined by titration of the $\mathrm{NaOH}$ solution following $\mathrm{BaCl}_{2}$ precipitation (23). Radioactivity remaining in the $\mathrm{NaOH}$ solution following titration was determined to assess trapping of volatiles.

\section{Fuometuron Degradation in Ryegrass Residues and Amended Soils}

Laboratory studies evaluated the interactions of moisture content of ryegrass residues and inoculation with soil on the degradation of fluometuron. Technical grade fluometuron was obtained from Chem Service, Chester, PA, and ${ }^{14} \mathrm{C}$-ring labelled fluometuron ( $>98 \%$ radiochemical purity) and metabolite standards were contributed by Ciba (now Novartis), Greensboro, NC. An aqueous soil suspension (1:10 w:w) of Dundee soil was prepared by shaking vigorously for $2 \mathrm{~h}$. Ryegrass residues, $1.18 \mathrm{~g}$ (1.00 g oven dry weight), were placed in centrifuge tubes ( $25 \mathrm{~mL}$ glass, screw cap). The residues were treated in one of three ways: $300 \mu \mathrm{L}$ of water, $300 \mu \mathrm{L}$ of soil suspension, or left untreated. The tubes were capped with polyurethane plugs, and samples were incubated for 48 $\mathrm{h}$ at $28{ }^{\circ} \mathrm{C}$. Residues were then treated with either $300 \mu \mathrm{L}$ of $32.3 \mu \mathrm{M}$ fluometuron solution $\left(16.7 \mathrm{KBq} \mathrm{mL}^{-1}\right.$ of

${ }^{14} \mathrm{C}$-ring labelled fluometuron), or $700 \mu \mathrm{L}$ of $13.85 \mu \mathrm{M}$ fluometuron solution $\left(7.1 \mathrm{KBq} \mathrm{mL}{ }^{-1}\right.$ of ring labelled fluometuron). These treatments resulted in three final moisture contents $(48,78$ and $118 \%$ water w/w basis) and a fluometuron concentration of $9.7 \mu \mathrm{mol} \mathrm{kg}{ }^{-1}$ ryegrass. Residues were incubated at $28{ }^{\circ} \mathrm{C}$ with triplicate tubes of the five treatments (three moisture contents in addition to the two highest moisture contents inoculated with soil extract) sampled at 4,7 , and $11 \mathrm{~d}$ after treatment.

The effects of incorporation of ryegrass residues in soil on fluometuron degradation were compared to nonamended soil from no cover crop (fallow) plots or soil collected from ryegrass plots. Dundee soil ( 0 to $2 \mathrm{~cm}$ sample) and residues were collected 1 month after application of glyphosate from no-tillage plots. Soil $(5.0 \mathrm{~g}$ air dried equivalent) was added to centrifuge tubes (25-mL screw cap). Finely-chopped ryegrass residues (100 $\mathrm{mg}$ of 1 to $2 \mathrm{~mm}$ pieces) were added to one set of tubes containing the soil from fallow plots and mixed well. Fluometuron solution ( $730 \mu \mathrm{L}$ containing $4167 \mathrm{~Bq}{ }^{14} \mathrm{C}$-ring labelled fluometuron), was added to attain $9.7 \mu$ mole $\mathrm{kg}^{-1}$ soil.. Four tubes of each treatment were sampled after incubating for 4,7 , and $11 \mathrm{~d}$ at $28^{\circ} \mathrm{C}$.

Fluometuron and metabolites were removed from residues and soils with four 15-mL methanol extractions (extraction efficiency $=99 \%$ ). Radioactivity recovered in each extract was determined by LSC, and the first two extracts were combined and reduced to $3 \mathrm{~mL}$ under $\mathrm{N}_{2}$ gas. Fluometuron and metabolites were determined by TLC and linear image scanning, using chloroform:ethanol (95:5, v:v) as solvent and silica gel plates as described elsewhere $(16,20)$. $R f$ values for standards were: fluometuron $=0.58$, desmethyl fluometuron $(D M F)=0.30$, trifluoromethyl phenylurea $($ TFMPU) $=0.13$, and trifluoromethyl aniline $($ TFMA $)=0.76$. Nonextractable radioactivity was determined in soils by oxidation as previously described in the 2,4-D study. 


\section{RESULTS AND DISCUSSION}

\section{Microbial populations and activity}

Microbial propagules recovered from soil were significantly influenced by hairy vetch and rye cover crops (Table 1). Overall, soils from hairy vetch plots had a greater stimulation of certain microbial groups, i.e. Gram-negative bacteria and fluorescent pseudomonads (May sample) compared to soil from rye plots. Similar effects were observed in other studies (10). Although a significant enhancement of certain soil microbial populations was observed due to cover crops, the magnitude of effects may have minimal effects on herbicide transformation and other microbial activity in soil. Cover crop residues maintained approximately 100 - to 1000 -fold greater propagule densities compared to the underlying surface soils; the magnitude of differences depended upon residue type, microbial group and date of sampling (Table 1). Similar levels of FDA hydrolytic activity were observed in soil regardless of cover crop (Table 2). Increased microbial populations, therefore, had little effect on this enzymatic

Table 1. Microbial propagules associated with soils and cover crop residues at two samplings.

\begin{tabular}{|c|c|c|c|c|}
\hline \multirow[b]{2}{*}{ Sample, Date } & \multicolumn{4}{|c|}{$\log (10)$ colony forming units $\mathrm{g}^{-1 \dagger}$} \\
\hline & Total Bacteria & $\begin{array}{c}\text { Gram-negative } \\
\text { Bacteria }\end{array}$ & $\begin{array}{l}\text { Fluorescent } \\
\text { Pseudomonads }\end{array}$ & $\begin{array}{l}\text { Total } \\
\text { Fungi }\end{array}$ \\
\hline \multicolumn{5}{|l|}{ Soils, May } \\
\hline Hairy vetch soil & $8.13 \mathrm{a}$ & $7.26 \mathrm{a}$ & $6.30 \mathrm{a}$ & $5.17 \mathrm{a}$ \\
\hline Rye soil & $8.12 \mathrm{a}$ & $6.89 \mathrm{~b}$ & $5.87 \mathrm{~b}$ & $5.21 \mathrm{a}$ \\
\hline No cover soil & $7.95 \mathrm{~b}$ & $6.44 \mathrm{c}$ & $5.36 \mathrm{c}$ & $5.22 \mathrm{a}$ \\
\hline \multicolumn{5}{|l|}{ Residues, May } \\
\hline Hairy vetch & $10.40 \mathrm{a}$ & $9.66 \mathrm{a}$ & $9.00 \mathrm{a}$ & $8.09 \mathrm{a}$ \\
\hline Rye & $10.16 \mathrm{~b}$ & $9.86 \mathrm{a}$ & $9.15 \mathrm{a}$ & $7.67 \mathrm{~b}$ \\
\hline \multicolumn{5}{|l|}{ Soils, July } \\
\hline Hairy vetch soil & $7.62 \mathrm{a}$ & $6.20 \mathrm{a}$ & $4.95 \mathrm{a}$ & $5.17 \mathrm{a}$ \\
\hline Rye soil & $7.25 \mathrm{~b}$ & $5.89 \mathrm{ab}$ & $5.02 \mathrm{a}$ & $4.72 \mathrm{ab}$ \\
\hline No cover soil & $7.20 \mathrm{~b}$ & $5.92 \mathrm{ab}$ & $4.76 \mathrm{a}$ & $4.63 \mathrm{~b}$ \\
\hline \multicolumn{5}{|l|}{ Residues, July } \\
\hline Hairy vetch & $10.48 \mathrm{a}$ & $9.21 \mathrm{a}$ & $8.08 \mathrm{a}$ & $6.54 \mathrm{a}$ \\
\hline Rye & $10.05 \mathrm{a}$ & $9.12 \mathrm{a}$ & $7.99 \mathrm{a}$ & $6.45 \mathrm{a}$ \\
\hline
\end{tabular}

\footnotetext{
${ }^{\dagger}$ Values are the mean of six samples; means within a column for a given type of sample and date followed by the same letter do not differ significantly at the $95 \%$ level by Fishers LSD.
} 
activity in soil. FDA-hydrolytic activity was also similar between hairy vetch and rye residues. However, cover crop residues had 7- to 12-fold greater FDA hydrolytic activity than their respective soils. FDA hydrolysis is a generic indicator of microbial activity (21). It is a broad substrate for esterases, lipases and certain proteases and is correlated with microbial respiration. Schnurer and Rosswall (21) found that FDA-hydrolysis was more rapid in straw than soil, similar to what we observed in the cover crop residues. The FDA hydrolytic activities observed in the cover crop residues may reflect both the greater microbial density as well as greater availability of suitable substrates to support microbial activity.

Table 2. Fluorescein diacetate-hydrolysis (esterase) activity of soils and cover crop residues.

\begin{tabular}{|llll|}
\hline Sample Date & & \multicolumn{2}{c|}{$\mu$ mol Fluorescein Formed $\mathrm{g}^{-1} \mathrm{~h}^{-1}{ }^{\dagger}$} \\
\cline { 2 - 4 } & Cover Crop & Soil & Cover Crop Residue \\
\hline May & Hairy Vetch & $200 \mathrm{~ns}$ & $1970 \mathrm{~ns}$ \\
& Rye & 206 & 1640 \\
& None & 196 & - \\
July & Hairy Vetch & $181 \mathrm{~ns}$ & $2075 \mathrm{~ns}$ \\
& Rye & 190 & 2215 \\
& None & 163 & - \\
\hline
\end{tabular}

${ }^{\dagger}$ Means within a column for a given sample date were not significantly different at the $95 \%$ level as determined by Fisher's LSD. ns = not significant.

\section{2,4-D Degradation}

Two laboratory studies assessed the potential for degradation of 2,4-D by rye and vetch residues relative to soil. Summaries of cumulative ${ }^{14} \mathrm{CO}_{2}$ evolution from these studies are presented in Figures 1 and 2. In Study 1, 77\% of the carboxyl-labelled 2,4-D was metabolized to $\mathrm{CO}_{2}$ by soil compared to less than $30 \%$ by residues of the two cover crops, and $60 \%$ of ring-labelled 2,4-D was mineralized to $\mathrm{CO}_{2}$ by soil compared to less than $10 \%$ by the crop residues during the 14-d incubation. In the second study, 82, 37, and 40\% of carboxyl-labelled 2,4-D was evolved as $\mathrm{CO}_{2}$ by soil, rye, and vetch, respectively. Mineralization of ring-labelled 2,4-D by soil was $47.9 \%$ compared to 12.9 and $17.2 \%$ by the rye and vetch residues, respectively. The parent compound and metabolites (dichlorophenol and volatile organic acids) could have been trapped in the $\mathrm{NaOH}$ solutions. Minimum radioactivity (typically less than $5 \%$ of initial from both ring- and carboxyl-label) was recovered in solutions following $\mathrm{BaCl}_{2}$ precipitation, indicating that our assessment of mineralization was representative of $\mathrm{CO}_{2}$ evolved. Higher rates of both ring and carboxyl-labelled 2,4-D degradation were observed by reducing the amount of cover crop residues by $50 \%$ in the biometer flasks. Lower $2,4-\mathrm{D}$ mineralization in the first study may be due to 

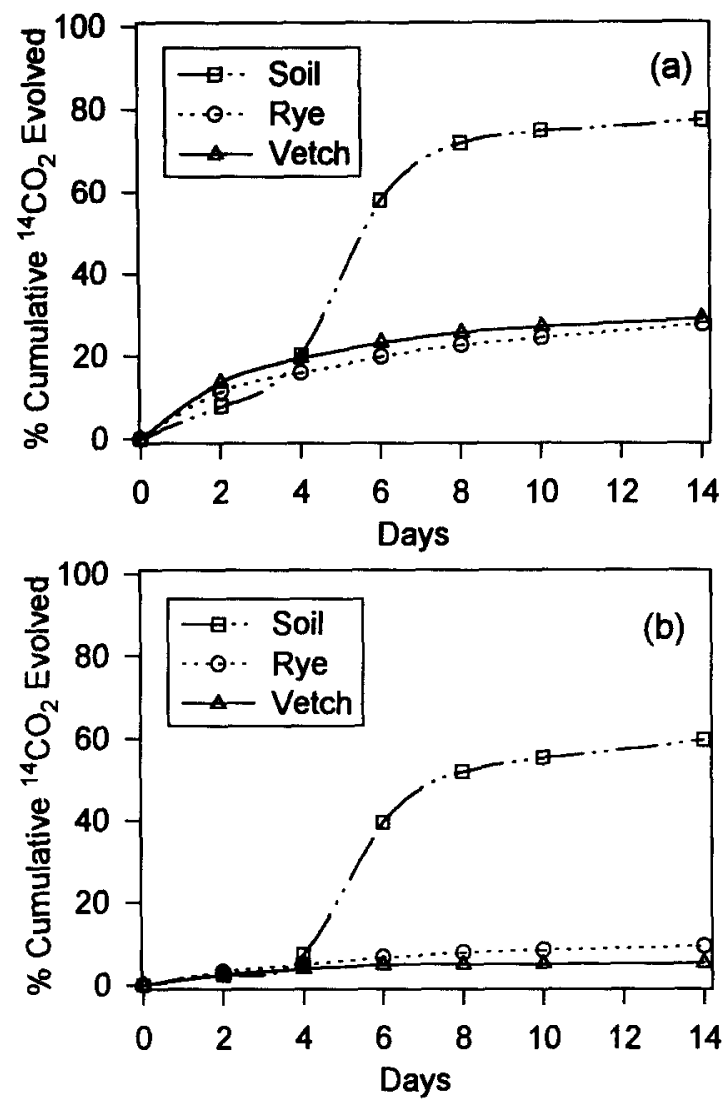

Fig 1. Mineralization of (a) ${ }^{14} \mathrm{C}$-carboxyl and (b) ring-labelled 2,4-D by soil, rye and hairy vetch residues, 2,4-D Degradation Study 1.

limited $\mathrm{O}_{2}$ availability caused by the amount of residue and subsequent respiration. However, trends in Study 1 are similar to those in Study 2 . In the second study, greater mineralization of ring labelled 2,4-D was observed in vetch compared to rye (Fig. 2). Higher rates of respiration (total $\mathrm{CO}_{2}$ evolution) were observed for the residues compared to soil. Respiration in rye was significantly greater $(\operatorname{Pr}>0.01)$ than vetch residues (Fig. 3). The respiration studies indicate that microbial activity was about 6- to 7-fold greater in the crop residues compared to soil during the 2,4-D degradation studies. The enhanced microbial activity observed in residues compared to soil (i.e., respiration and FDA hydrolysis), however, did not result in greater 2,4-D mineralization. A summary of the recovery of ${ }^{14} \mathrm{C}$-ring labelled 2,4-D is presented in Table 3. In both studies, a greater proportion of the radioactivity added was extractable from rye and vetch residues than from soil. TLC analysis of extracts from the second experiment indicated that all radioactivity corresponded to 2,4-D with no accumulation of metabolites (data not shown). A similar distribution of ${ }^{14} \mathrm{C}$ in the nonextractable fraction was observed for soil and residues in both studies. However, the ratio of ${ }^{14} \mathrm{C}$ mineralized compared to nonextractable in soil was 1.83 and 1.04 , while 
this ratio in the two cover crop residues was 0.23 (rye) and 0.36 (vetch). These results suggest that incorporation of 2,4-D or its metabolites into humic components or microbial biomass was the dominant fate of this herbicide in crop residues. Metabolism of certain herbicides may be restricted or altered under certain high organic matter situations. Locke and Harper (29) noted reduced mineralization of metribuzin when soybean residues were added to a Dundee silt loam compared to nonamended soil. Their data, however, indicate that residue-amended soil exhibited similar dissipation of extractable metribuzin to non-amended soil. In another study, low mineralization $(<2 \%)$ of chlorimuron-ethyl was observed in hairy vetch or rye residues, while greater than $15 \%$ was mineralized in soil during a 28-d incubation (30).

The microbial metabolism of 2,4-D proceeds via an initial cleavage of the ether-linked acetic acid side-chain which is readily metabolized to $\mathrm{CO}_{2}$ prior to metabolism of the dichlorophenol ring $(20,25)$. Based upon
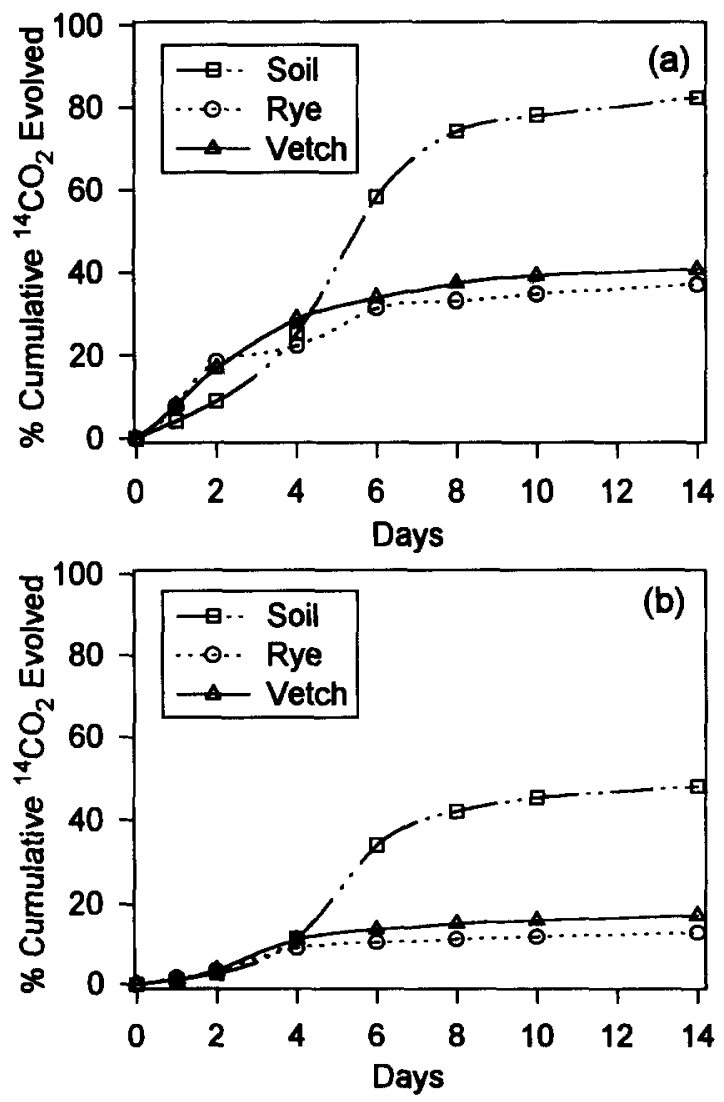

Fig 2. Mineralization of (a) ${ }^{14} \mathrm{C}$-carboxyl and (b) ring-labelled 2,4-D by soil, rye and hairy vetch residues, 2,4-D Degradation Study 2. 


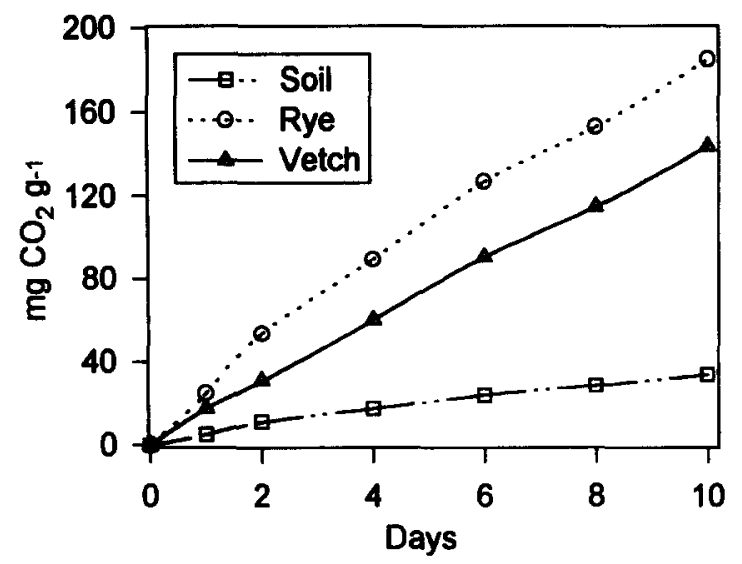

Fig 3. Cumulative respiration in soils and residues, 2,4-D Degradation Study 2.

patterns of ${ }^{14} \mathrm{CO}_{2}$ evolution, this is the case for both soil and cover crop residues. Initially, mineralization of the side-chain was greater for both cover crops than for soil (day 1 and 2). Following a 2-to 4-d lag period, the carboxyl group was rapidly mineralized to $\mathrm{CO}_{2}$ in soil, while rates of carboxyl-labelled metabolism were progressively reduced after day 4 in the cover crop residues. Mineralization of the ring-labelled 2,4-D in soil exhibited a 4-d lag; thereafter following rapid mineralization similar to the carboxyl labelled 2,4-D. A lag followed by rapid mineralization of both carboxyl and ring-labelled 2,4-D in soil suggests adaptation of the

Table 3. Fate of ${ }^{14} \mathrm{C}$-ring labelled 2,4-D, 14 days after application to soil or vetch and rye residues in two experiments.

\begin{tabular}{|lccc|}
\hline & \multicolumn{3}{c|}{${ }^{14} \mathrm{C}$ recovered, (\% of applied) ${ }^{\dagger}$} \\
\cline { 2 - 4 } Source & $\mathrm{CO}_{2}$ Mineralized & Extractable & Nonextractable \\
\hline Experiment 1 & & & \\
Soil & $59.6 \mathrm{a}$ & $7.9 \mathrm{~b}$ & $32.5 \mathrm{a}$ \\
Hairy vetch & $5.3 \mathrm{~b}$ & $71.3 \mathrm{a}$ & $23.4 \mathrm{a}$ \\
Rye & $9.4 \mathrm{~b}$ & $63.6 \mathrm{a}$ & $27.0 \mathrm{a}$ \\
Experiment 2 & & & $45.9 \mathrm{a}$ \\
Soil & $47.9 \mathrm{a}$ & $6.2 \mathrm{~b}$ & $47.4 \mathrm{a}$ \\
Hairy vetch & $17.2 \mathrm{~b}$ & $35.1 \mathrm{a}$ & $48.9 \mathrm{a}$ \\
Rye & $12.9 \mathrm{c}$ & $38.2 \mathrm{a}$ & \\
\hline
\end{tabular}

${ }^{\dagger}$ Mean of six replicates, means within a column for a particular study followed by the same letter do not differ at the $95 \%$ probability level as determined by Fishers LSD. 
microbial population to degrade 2,4-D. Microbial adaptation to 2,4-D has been reported for several soils (18, 19). Substantial population increases of 2,4-D degraders also occur during exposure to 2,4-D. Although higher microbial populations and activities (e.g., FDA hydrolysis and respiration) were observed in rye and vetch, higher mineralization of the carboxyl-labelled compared to ring-labelled 2,4-D in the residues suggests that degradation of 2,4-D in plant residues was less extensive than in soil. Typically, a greater proportion of carbon from the sidechain of 2,4-D can be incorporated into microbial biomass compared to that from the ring-labelled moiety of 2,4-D (20). The dichlorophenol ring can also be subjected to enzyme-mediated oxidative coupling reactions (26, 27), resulting in polymerization into humic compounds. Oxidoreductive enzymes such as tyrosinases, laccases and peroxidases are present in many fungi and certain bacteria associated with plant residues. Reducing the cover crop residue mass by $50 \%$ doubled the incorporation of ring-labelled 2,4-D into nonextractable components, indicating an oxygen-dependent reaction. Nonextractable radioactivity measured in our studies can be explained as amount of initial 2,4-D either incorporated into microbial biomass and/or incorporated into either humic or lignocellulose materials.

\section{Fluometuron Degradation}

Fluometuron degradation in ryegrass residues was significantly affected by moisture content (Fig. 4).

Fluometuron was sequentially demethylated to DMF and TFMPU as described elsewhere $(16,20,27,28)$.

Minimal fluometuron degradation was observed at the lowest moisture content, as only $11 \%$ was transformed to DMF, and no TFMPU was detected. At the highest moisture content, greater than $65 \%$ of the radioactivity was recovered as DMF and TFMPU. The greatest accumulation of TFMPU occurred at the highest moisture content and degradation was comparable to soil (Table 4). During this short-term assay, greater than $97 \%$ of the radioactivity was methanol-extractable in all treatments (thus nonextractable ${ }^{14} \mathrm{C}$ was not determined) and no formation of TFMA was observed. Pre-treatment of the residues with soil suspensions had no effect on fluometuron degradation at the intermediate moisture content, however inoculation with soil extract enhanced fluometuron degradation at the highest moisture content. This suggests that microflora associated with the ryegrass residues may not have been as effective in fluometuron degradation as soil microflora present in soil with a long-term history of fluometuron exposure. The bioavailability of substrates for microbial degradation in soil can also be limited by interactions between water potential and sorption as was demonstrated for the insecticide carbofuran (28). The high lignocellulose component of plant materials enables a greater water holding capacity compared to mineral soils. The adjusted moisture content of residues used in these studies was greater than that typically observed under field conditions ( 15 to $30 \%$ moisture, unpublished field observations). This was evident in these studies where minimal fluometuron transformation occurred in ryegrass at $48 \%$ moisture, while degradation rates similar to soil (Table 4) were observed at $118 \%$ moisture. The degradation of fluometuron was more rapid in soil collected from no-till ryegrass plots than in soils from bare ground no-till plots (Table 4), confirming previous observations (16). Incorporating ryegrass into soil from bare ground no-till plots resulted in the most rapid fluometuron dissipation and accumulation of $N$-dealkylated metabolites (Table 4). Our previous 


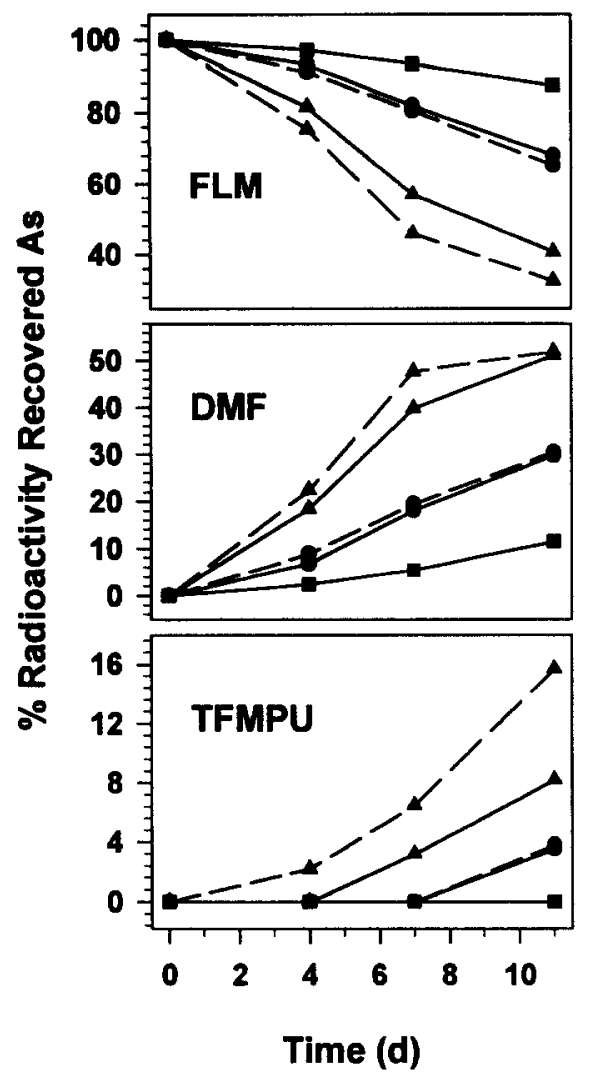

Fig 4. Effect of moisture content and inoculation with soil extract on fluometuron degradation in treated (dashed line) and nontreated (solid line) ryegrass residues; FLM = fluometuron, DMF = desmethyl fluometuron, and TFMPU = treated trifluoromethyl phenylurea. $=48 \%$ moisture, $\bullet=78 \%$ moisture, $\triangle=118 \%$ moisture.

studies also indicated that fluometuron degradation proceeded more rapidly in surface no-till soils where either the ryegrass residues remained on the soil surface or where the ryegrass was incorporated into the soil by tillage. Compared to ryegrass residues, a rapid incorporation of ${ }^{14} \mathrm{C}$ into methanol-nonextractable soil components was observed ( 15 to $25 \%$ after $11 \mathrm{~d}$ ). The highest levels of TFMPU accumulation and nonextractable ${ }^{14} \mathrm{C}$ were observed in soil amended with ryegrass. Other studies (24) have shown that ryegrass is an effective biostimulating amendment to enhance the degradation of high concentrations of cyanazine and fluometuron in soils. Amending soil with ryegrass, or perhaps other crop residues, provides carbon substrate to enhance soil microbial activity, resulting in enhanced potential for herbicide degradation. Use of a fall-seeded cover crop such as ryegrass, under either a no-till or conventional tillage system, may decrease the persistence of fluometuron in soil applied the following spring. Plant residues such as herbicide-desiccated cover crops are predominantly 
Table 4. Fluometuron degradation in no-till Dundee silt loam soil from winter fallow plots, annual ryegrass plots, and fallow plots amended with $2 \%$ ryegrass residues

\begin{tabular}{|c|c|c|c|c|}
\hline \multirow{2}{*}{$\begin{array}{l}\text { Time (d), } \\
\text { Treatment }\end{array}$} & \multicolumn{4}{|c|}{$\%{ }^{14} \mathrm{C}$ Initially Applied Recovered as ${ }^{\dagger}$} \\
\hline & Fluometuron & DMF & TFMPU & Nonextractable \\
\hline 4, Fallow soil & $90.7 \mathrm{a}$ & $3.7 \mathrm{~b}$ & nd & $3.8 \mathrm{c}$ \\
\hline 4, Ryegrass soil & $85.6 \mathrm{~b}$ & $12.8 \mathrm{a}$ & nd & $5.8 \mathrm{~b}$ \\
\hline $\begin{array}{l}\text { 4, Ryegrass added } \\
\text { to fallow soil }\end{array}$ & $72.9 \mathrm{c}$ & $13.8 \mathrm{a}$ & $2.7 \mathrm{a}$ & $7.1 \mathrm{a}$ \\
\hline 7, Fallow soil & $67.3 \mathrm{a}$ & $26.6 \mathrm{a}$ & $0.6 \mathrm{c}$ & $6.1 \mathrm{c}$ \\
\hline 7, Ryegrass soil & $57.1 \mathrm{~b}$ & $29.8 \mathrm{a}$ & $2.9 \mathrm{~b}$ & $9.1 \mathrm{~b}$ \\
\hline $\begin{array}{l}\text { 7, Ryegrass added } \\
\text { to fallow soil }\end{array}$ & $51.9 \mathrm{c}$ & $30.8 \mathrm{a}$ & $4.8 \mathrm{a}$ & $11.0 \mathrm{a}$ \\
\hline 11, Fallow soil & $50.7 \mathrm{a}$ & $32.5 \mathrm{a}$ & $1.8 \mathrm{c}$ & $14.9 \mathrm{c}$ \\
\hline 11, Ryegrass soil & $42.9 \mathrm{~b}$ & $30.2 \mathrm{a}$ & $3.7 \mathrm{~b}$ & $20.5 \mathrm{~b}$ \\
\hline $\begin{array}{c}\text { 11, Ryegrass added } \\
\text { to fallow soil }\end{array}$ & $35.1 \mathrm{c}$ & $32.1 \mathrm{a}$ & $3.7 \mathrm{~b}$ & $24.2 \mathrm{a}$ \\
\hline
\end{tabular}

${ }^{\dagger}$ Values are mean of four replicates; means within a column for a given sample date followed by the same letter do not differ significantly at the $95 \%$ level. nd $=$ not detected.

composed of lignin, cellulose and hemicellulose and differences in this composition can be attributed to species and duration of aging in the field (31). A 3-fold greater sorption of 2,4-D, alachlor and acifluorfen was observed in rye and hairy vetch residues compared to soil (32). Freundlich sorption parameters (Kf) for 2,4-D were 3.98, 4.34 and 1.21 for rye, vetch, and soil, respectively. In another study (15), chlorimuron-ethyl had greater potential for sorption to hairy vetch residues compared to rye residues, which were greater than soil. Fluometuron (16) had higher sorption potential to hairy vetch $(K f=28.0)$ compared to rye $(K \dot{f}=21.8)$ and sorption by both residues was greater than soil $(K f=2.6)$. The greater sorption of herbicides in hairy vetch compared to rye may be due to higher lignin content as postulated by Reddy et al. (15). 
Although metribuzin is highly absorbed by wheat straw, there was minimal sorption of metribuzin to cellulose from wheat straw (33), implicating lignin as the component responsible for sorption of this herbicide. The greater potential for sorption in crop residues compared to soil could reduce the amount of 2,4-D or fluometuron in solution, thus restricting the bioavailability for microbial degradation. The role of sorption in limiting 2,4-D degradation in crop residues is supported by the observation that initially rapid rates of carboxyl mineralization were observed in the initial 2 to $4 \mathrm{~d}$ of the studies, followed by a rapid decline in mineralization rates. There may also be a difference in microbial populations capable of degrading 2,4-D in crop residues compared to soils, and this would be suitable topic for further study.

\section{SUMMARY AND CONCLUSIONS}

Our studies indicate that herbicide-desiccated cover crop residues are biologically more active than their underlying soils, however the degradation of 2,4-D is less extensive in crop residues than in soil. $N$-demethylation of fluometuron in cover crop residues can proceed as rapidly as soil, but only under high moisture conditions. These results suggest that physical-chemical factors such as sorption of the herbicides to lignocellulose components of the plant residues may reduce the effective solution concentration, thus impeding bioavailability and subsequent biodegradation. The potential for biodegradation of other herbicides by crop residues and interactions between sorption and bioavailability needs to be elucidated to understand the impacts of crop residue management systems on herbicide efficacy and environmental fate. Direct seeding into herbicide-desiccated cover crop residues may offer many environmentally desirable benefits such as moisture conservation, erosion and weed control. However, interception of herbicides by surface crop residues may prolong their persistence by rendering them unavailable for biodegradation, especially under low moisture conditions.

\section{ACKNOWLEDGMENTS}

The technical contributions of Richard E. Gordon, Mary E. Smyly and Albert L. Tidwell are greatly appreciated. We are grateful to Ciba (Novartis) for providing radiolabelled fluometuron and analytical standards of fluometuron metabolites.

\section{REFERENCES}

1. R.W. Liebl, W. Simmons, L.M. Max, and E.W. Stoller, Effect of rye mulch on weed control and soil moisture in soybean (Glycine max), Weed Technol. 6, 838-846 (1992).

2. J.R. Teasdale, C.E. Beste, and G.D. Lytle, Response of weeds to tillage and cover crops, Weed Sci., 39, 195199 (1991).

3. L.A. Weston, Cover crop and herbicide influence on row crop seeding establishment in no-tillage culture, Weed Sci. 38, 166-171 (1990).

4. A.A. Fahad, L.N. Mielke, A.D. Flowerday, and D. Schwartzendruber, Soil physical properties as affected by soybean and other cropping sequences, Soil Sci. Soc. Am. J. 46, 377-381 (1982). 
5. V.O. Biederbeck, C.A. Campbell and R.P. Zentner, Effect of crop rotation and fertilization on some biological properties of soil, Can. J. Soil Sci. 64, 355-367 (1984).

6. W.A. Dick, Influence of long-term tillage and crop rotation combinations on soil enzyme activities. Soil Sci. Soc. Am. J. 48, 569-574 (1984).

7. S.C. Wagner, R.M. Zablotowicz, M.A. Locke, R.J. Smeda, and C.T. Bryson, Influence of herbicidedesiccated cover crops on biological soil quality in the Mississippi Delta, Proceedings of the Southern Conservation Tillage Conference for Sustainable Agriculture (Edited by W.L. Kingery and N.W. Buehring), pp. 86-89. Mississippi Agric. Forestry Exper. Sta. Spec. Bull. 88-7 (1995).

8. M.A. Locke, L.A. Gaston, and R.M. Zablotowicz, Alachlor biotransformation and sorption in soil from two soybean tillage systems, J. Agric. Food Chem. 44, 1128-1134 (1996).

9. D. Levanon, J.J. Meisinger, E.E. Codling, and J.L. Starr, Impact of tillage on microbial activity and fate of pesticides in the upper soil, Water, Air, and Soil Pollution 72, 179-189 (1994).

10. S.C. Wagner, R.M. Zablotowicz, L.A. Gaston, and M.A. Locke, and J. Kinsella, Bentazon degradation in soil: Influence of tillage and history of bentazon application, J. Agric. Food Chem 44, 1593-1598 (1996).

11. K.N. Reddy, R.M. Zablotowicz, and M.A. Locke, Chlorimuron adsorption, desorption, and degradation in soils from conventional and no-tillage systems, J. Environ. Qual. 24, 760-767 (1995).

12. M.A. Locke and S.S. Harper, Metribuzin degradation in soil: II-Effects of tillage, Pestic Sci. 31, 239-247 (1991).

13. P.A. Banks, and E.L. Robinson, The influence of straw mulch on the reception and persistence of metribuzin, Weed Sci. 30, 164-168 (1982).

14. P.A. Banks and E.L. Robinson, Soil reception and activity of acetochlor, alachlor, and metolachlor as affected by wheat (Triticum aestivum) straw and irrigation, Weed Sci. 34, 607 -611 (1986).

15. K.N. Reddy, M.A. Locke, S.C. Wagner, R.M. Zablotowicz, L.A. Gaston and RJ. Smeda, Chlorimuronethyl sorption and desorption kinetics in soils and herbicide-desiccated cover-crop residues, J. Agric. Food Chem. 43, 2752-2757 (1995).

16. M.A. Locke, R.M. Zablotowicz, and L.A. Gaston, Fluometuron interactions in crop residue managed soils, Proceedings of the Southern Conservation Tillage Conference for Sustainable Agriculture (Edited by W.L. Kingery and N.W. Buehring), pp. 55-58. Mississippi Agric. Forestry Exper. Sta. Spec. Bull. 88-7 (1995).

17. J.C. Fournier, P. Codacconi, and G. Soulas, Soil adaption to 2,4-D degradation in relation to the application rates and the metabolic behaviour of the degrading microflora, Chemosphere 10, 977-984 (1981).

18. L.T. Ou, 2,4-D degradation and 2,4-D degrading microorganisms in soils, Soil Sci. 137, 100-107 (1984).

19. D.E. Stott, J.P. Martin, D.D. Focht, and K. Haider, Biodegradation, stabilization in humus and incorporation into soil biomass of 2,4-D and catechol carbons, Soil Sci Soc. Am. J. 47, 66-70 (1983).

20. G.A. Bozarth, and H.H. Funderburk Jr., Degradation of fluometuron in sandy loam soil, Weed Sci. 19, 691695 (1971). 
21. J. Schnurer and T. Rosswall, Fluorescein diacetate hydrolysis as a measure of total microbial activity in soil and litter, Appl. Environ. Microbiol. 43, 1256-1261 (1982).

22. R. Bartha and D. Pramer, Features of a flask and method of measuring the persistence and biological effects of pesticides, Soil Sci. 100, 68-70 (1965).

23. J.P.E. Anderson, Soil Respiration, In Methods of soil analysis Part 2 - Chemical and Microbiological properties (Edited by A. Page, R.H. Miller, and R. Keeney), pp. 831-872, Am. Soc. Agron., Madison WI (1982).

24. S.C. Wagner and R.M. Zablotowicz, Effect of organic amendments on the bioremediation of cyanazine and fluometuron in soil, J. Environ. Health Sci. Sec. B 32, $37-54$ (1997).

25. J.M. Tiedje, and M. Alexander, Enzymatic cleavage of the ether bond of 2,4-dichloroacetate, J. Agric. Food Chem. 17, 1080-1084 (1969).

26. J. Dec and J.-M. Bollag, Dehalogenation of chlorinated phenols during oxidative coupling, Environ. Sci. Technol. 28, 484-490 (1994).

27. J.M. Sarkar, R.L. Malcolm, and J.M. Bollag, Enzymatic coupling of 2,4-dichlorophenol to stream fulvic acid in the presence of oxidoreductases, Soil Sci. Soc. Am. J. 52, 688-694 (1988).

28. D.R. Shelton and T.B. Parkin, Effect of moisture and sorption and biodegradation of carbofuran in soil, $J$. Agric. Food Chem. 39, 2063-2068 (1991).

29. M.A. Locke and S.S. Harper, Metribuzin degradation in soil: I-Effects of residue amendment, metribuzin level and soil depth, Pestic. Sci. 31, 221-237 (1991).

30. S.C. Wagner, R.M. Zablotowicz, K.N. Reddy, M.A. Locke, and R.J .Smeda, Chlorimuron mineralization under herbicide-desiccated rye and vetch cover crops, Weed Sci. Soc. Am. Abstracts 35, 77 (1995).

31. M.G. Wagger, Time of desiccation effects on plant composition and subsequent nitrogen release from several winter annual cover crops, Agron. J. 81, 236-241 (1989).

32. M.A. Locke, R.M. Zablotowicz, L.A. Gaston, and R.J. Smeda, Sorption of herbicides to cover crop residues, Am. Soc. Agron. Abstracts 86, 50 (1994).

33. T.H. Dao, Field decay of wheat straw and its effects on metribuzin and S-ethyl metribuzin sorption and elution from crop residues, J. Environ. Qual. 20, 203-208 (1991). 